\title{
A Pestle Analysis of Maritime Piracy and Maritime Security in the Gulf of Guinea
}

\author{
Dr. Capt. Nana Raymond Lawrence Ofosu-Boateng \\ Regional Maritime University, Accra - Ghana \\ Dr. Zhang Jiping \\ Jiaxing University, Jiaxing- China
}

\begin{abstract}
The Gulf of Guinea is a region that that draws a lot of interest to many nations in Latin America, Europe and West Africa. It is because these countries depend on this region for conducting their business. Most of the countries export their products and import other goods through the Atlantic Ocean (Ali, 2017). The discovery of oil in Nigeria led to increased business transaction in this region and thus, the development of the economy. However, it also led to the rise of piracy, which affected the maritime security of the area. Many ships and other sea vessels have been affected by the acts of pirates who attack the ships and steal the content being transported. Sometimes they could also hijack these vessels and demand for ransom for them to be released. The ability to counterattack the pirates and robberies in this region is affected by factors which range from political, economic, social, technological, legal, and environmental. Matters such weak governments and poor implementation of the laws and conventions make the countries in the region to lack ability to tackle pirates in the sea and thus have to rely on the international security agencies like Interpol policing and other forces to help in providing security in the sea (Hasan, \& Hassan, 2016). Increase in population, lack of unemployment, and poverty are also some of the things which makes many youths in the region to participate in these criminal activities because they lack something constructive, which can generate income.
\end{abstract}

\section{INTRODUCTION}

\section{A Pestle Analysis of Maritime Piracy and Maritime Security in the Gulf of Guinea}

The Gulf of Guinea has been experiencing an increase in the rate of insecurity issues which coupled with the robberies in the local water territories and piracy in the deep sea. Many factors have contributed to the increase in the insecurity in the Gulf of Guinea. One if this is the fact that the international community has placed more focus on the Gulf of Africa and the Somali coast which is the area that has been in highlight most of the time for hijacking cargo ships and demanding a high amount of ransom from the companies which own those ships. The area is also considered to be posing a global challenge when it comes to piracy (Hasan, \& Hassan, 2016). It is because the Somali coast is dominated by the pirates linked to the Somali terrorists.

Furthermore, there is no working government in Somalia as a result of the fights which has persisted in the region for a long time. These are some of the considerations that have made the international community turned their attention to the fight against Somali piracy and neglected other regions such as the Gulf of Guinea. While the focus was on the coast water of east Africa, it allowed the piracy activities in guinea to take place. The purpose of documenting this article is to conduct a pestle analysis of maritime piracy and maritime security in the Gulf of Guinea. 
The figure below shows the maritime region of the Gulf of Guinea (Kamal-Deen, 2015).

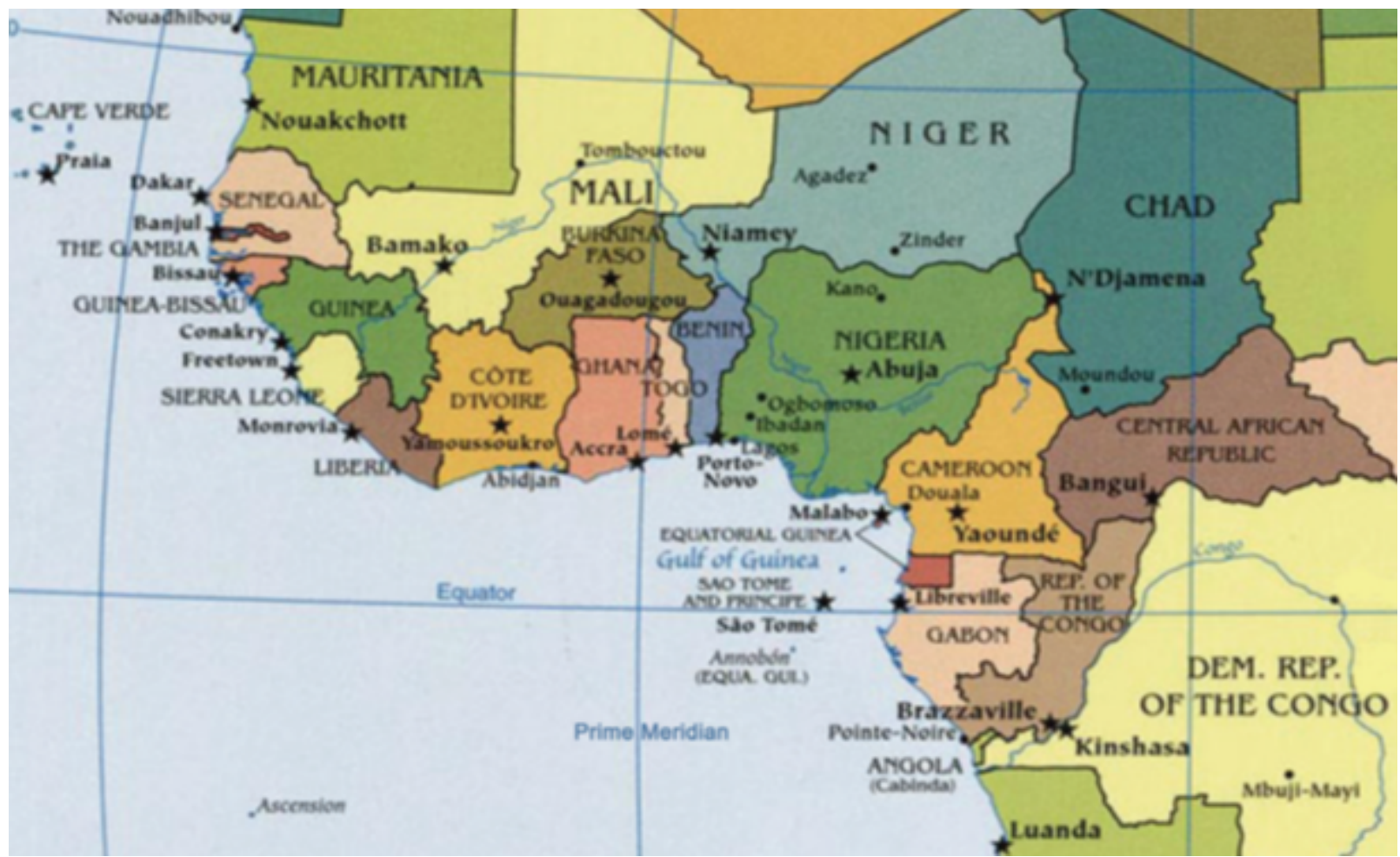

Source: GISIS, IMO, UNITAR/UNOSAT, 2014.

\section{POLITICAL}

Many political issues in the West Africa region are contributing to the piracy or maritime insecurity in the coastal waters and the deep sea, beyond the jurisdiction of any nation. One of these concerns is sea blindness. Countries in this region do not have sufficient knowledge concerning their responsibility on the area of the ocean under control and even the deep sea. The government gives little attention to what is going on their waters. Due to this, the government has failed to support research activities to be conducted in the deep sea and which would have helped those in authority to have information concerning what is taking place in their waters and thus avail recommendation on what can be done to improve maritime security in their waters. Due to this, the pirates have taken advantage of this opportunity to organise and conduct their acts of piracy by attacking many ships which are either originating from this particular region or those which are crossing these waters form other nations (Ali, 2017). Sea blindness is, therefore, one of the main obstacles that are contributing to the failure of both local and international security agencies to cope with insecurity issues that are emerging in this region.

Another factor that is contributing to the rise in pirates activities in the deep sea and robberies in the coastal waters in this region is political instability in some of the countries like Cote d'Ivoire. Nigeria, for example, has experienced many uprises in the Niger Delta because the communities living in this region think that the government has marginalised them by taking the land they used to practice agricultural activities and yet they receive little money generated from oil exploration done on their communal area. As a way of expressing their anger, some people from these communities, especially the young men, have been organising gangs who attack the trucks that are transporting oil and steal the content that is being carried. They have also been reported to vandalise the pipelines that are used to transport fuels to the refineries or storage facilities (Brown, 2016). They later sell oil that they succeed to steal in the process to the oil bunkers in the black market. The countries which have been experiencing such 
political turmoil in the mainland makes its forces to concentrate in protecting combating such challenges in the shore to maintain order and thus makes it hard for them to control also what is happening in the deep sea. It is because it forces the government to focus on providing security to law-abiding people in the nation.

Furthermore, it will not be possible for that nation to send its forces to patrol in the deep sea while there is unrest back home. The respective governments also find it hard for the neighbouring countries to come together to talk on how they can boost the security in the ocean as a region. It is also important to note that most of the countries in this region are not strong politically, and their forces are not well equipped for deep sea battles (Sposato, 2016). Most of the equipment used by the navy in this region are using old technology which makes it hard to tackle the pirates who bought modern facilities from the money they generated in the sea, such as ransom from the ship they had captured or oil they sell in the black markets.

Despite these challenges, maritime security is going to improve following the involvement of other nations such as the Dutch government is setting up their counter-piracy forces in the Gulf of the guinea to fight piracy. The Dutch government has increased its involvement in West Africa and has opened its embassy in Nigeria recently. Nigeria is also one of the counties that have been profoundly affected by the activities of the pirates in the deep sea (Denton, \& Harris, 2019). The willingness of the Dutch government to send its forces in the Gulf of Guinea is because many Dutch companies are involved in oil and gas in some of the countries in this region like Nigeria. It, therefore, forces the Dutch forces to commit itself in ensuring the security of its ships which sail across this region frequently. The presences of these forces in the Gulf of Guinea are seen as one of the most significant moves that have helped to boost the maritime security in this region. The support of the United Nations in the fight against piracy in the deep seas has also contributed to keeping the act of pirates under control.

\section{ECONOMIC}

The business in the Gulf of Guinea is propagated by the presence of the oil and other minerals in like diamond found in this region. Oil exploration, especially in Nigeria, has had an impact on the economy in this region. It is the leading natural commodity that brings money to this region. The demand for oil in the world is high, and that is the reason why this commodity fetches high prices in the market. It has favoured the national government in the respective countries because it has enabled it to generate more revenue.

On the other hand, this did not favour the communities who are living in the areas which are prone to oil exploration. It is because these communities were traditionally farmers, and thus when oil exploration began in this region, they were affected economically. They had to be displaced from their fertile land to pave the way for the companies conducting oil exploration (Johnson, 2018). In this way, they were affected economically because the government did not take the necessary initiative of ensuring that these people are settled somewhere else where they would continue with their economic activities. Most the young men in this region started engaging in the black market where they could buy oil with low prices and sell it at a profit. In this way, they empowered themselves economically. They also encourage piracy to grow because they provide a ready market for the oil stolen from the ships that they capture in the deep seas. Availability of ready market for the oil taken made those conducting the piracy in the deep sea to empower themselves economically. They also use the money they generate from this trade to buy weapons, boats and other vessels they use for their activities in the sea. The kind of investment that those pirates do back at home shows that they are getting a lot of money in the sea. Many youths thus get attracted to engage in piracy and other robberies in the 
sea. The rising number of young men who are participating in criminal activities the ocean has greatly affected maritime security in the region.

Statistics show that every year, there are around 1000 attempted cases of hijacking the ships that are operating in his region (Osinowo, 2015). Such situations make it hard for people to conduct their business well across the ocean because of insecurity. It has, therefore, affected the economy of the countries existing in the area.

The graph is showing a comparison of the revenues generated from some of the products produced in the region (Omeje, 2017).

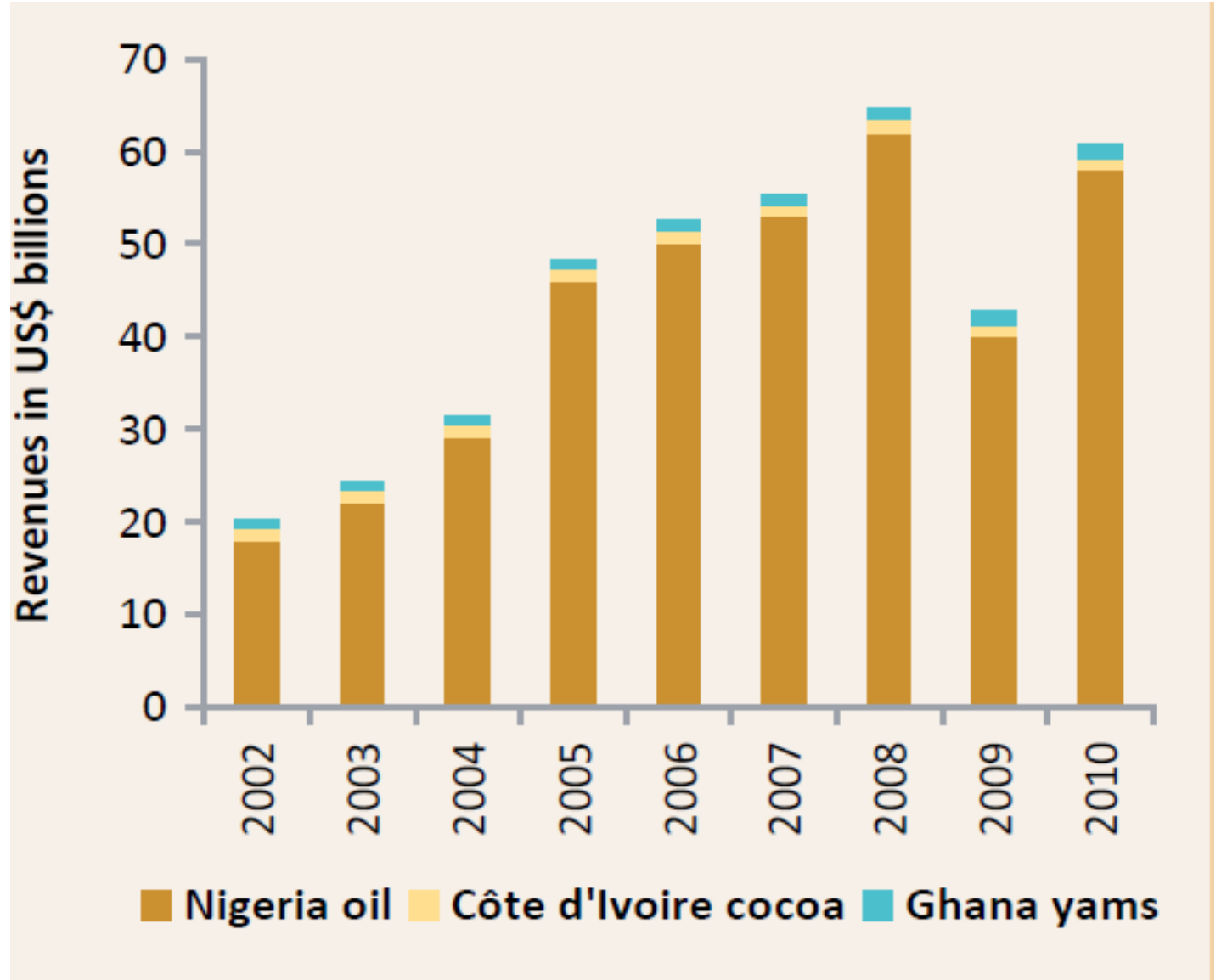

Source: OPEC, FAO STAT121

SOCIAL

Another factor that is posing a challenge to maritime security in the Gulf of Guinea is the ever rising population in this region. The increase in population has led to competition for limited resources available in the nation. Those who are profoundly affected are the youths because of reasons such lack of capital to get into business or to sponsor their education and lack of jobs. In the Niger Delta region alone, for example, is home to 30 million people. Thirty per cent of this population is unemployed, the majority being the youths (Nelissen, 2018). The existence of a large population of teenagers who are not employed is a challenge to the security of the nation and even maritime security. It is because they can quickly be recruited in to join the pirates because most of them are desperate to earn a living. Since it is hard to get a legal job to do, these youths would consider piracy as the only option for them to use to get out of poverty. This trend is the same in a country like Gabon, where research shows that more than thirty per cent of the entire population in the nation does not have jobs (Denton, \& Harris, 2019). Thirteen per cent of this population is considered to be living in severe poverty. With such 
kind of suffering, these youths can accept to engage in any activity even if it is robberies in the local water or smuggling of drugs.

The graph below shows the rate of unemployment in Nigeria. The figures are in percentage (Frank, 2017).

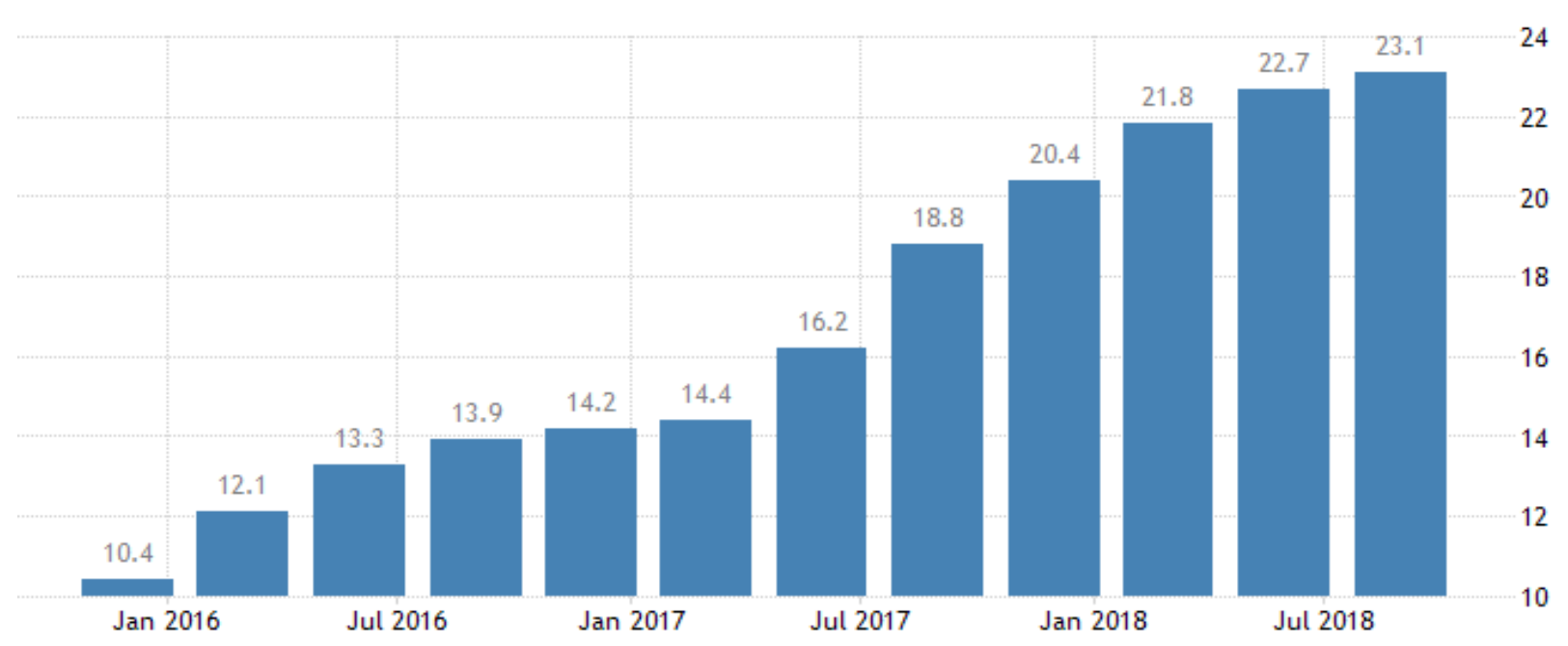

Source: Tradingeconomic.Com | Bureau of Statistics, Nigeria.

When they happen to hear about the amount of money received by those who engage in piracy as ransom when they arrive to capture a ship in the deep sea, they are willing to get the assistance of those people to be recruited into the same activity. Those youths endanger their lives the sea waters because they do not have experience of sailing in the deep sea. However, because of the amount of money they hope to get in the process, they feel encouraged to risk floating in the deep sea or get arrested by the forces which are concerned with providing securities in this region.

The graph below shows the resent population growth in Nigeria (Frank, 2017).

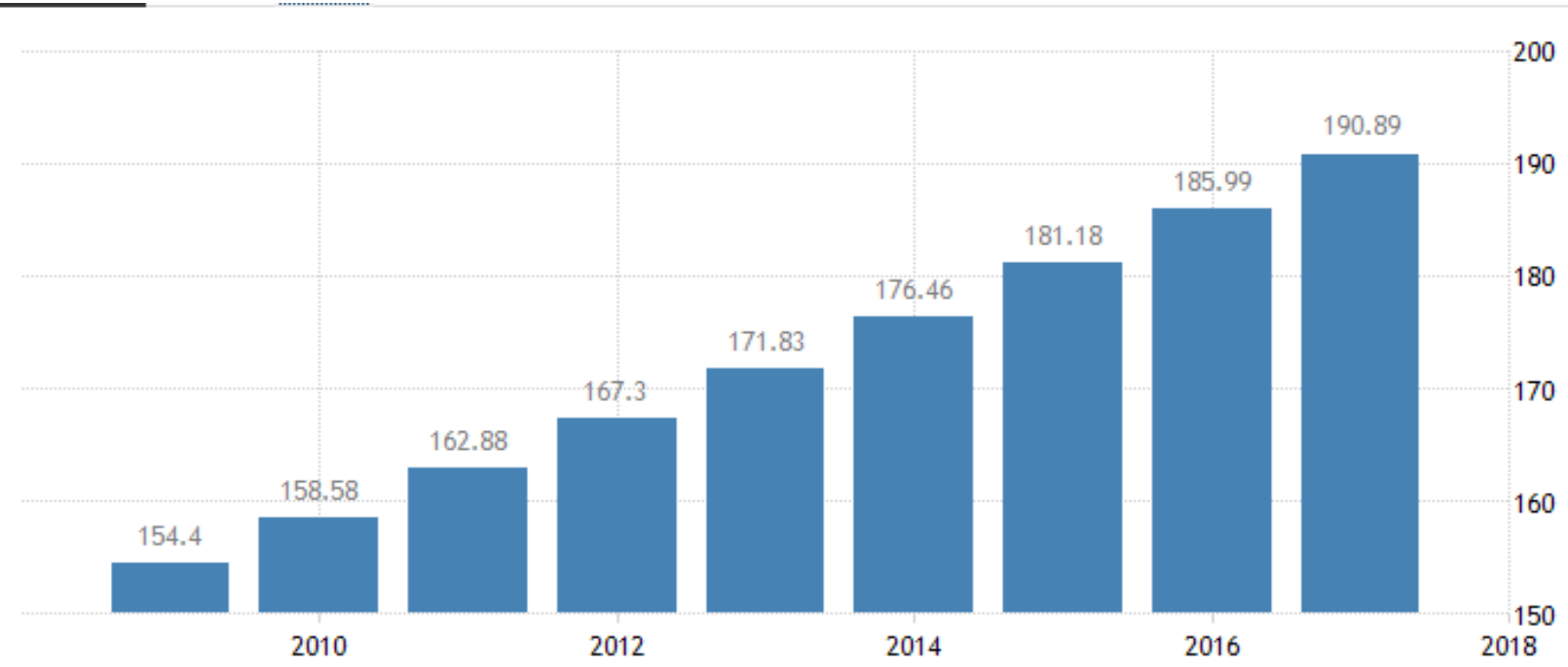

Source: Tradingeconomic.Com Bureau of Statistics, Nigeria.

Retrieved from: https://d3fy651gv2fhd3.cloudfront.net/charts/nigeria-unemployment- 
Those who will not be able to join experienced pirates in the sea will group up and contribute money they need to buy boats they will use for robberies in the local water. Those who do not have resources to buy their vessels will start by stealing the boats from people are conducting fishing in the ocean (Frank, N. J. (2017). They will then use the same vessels to conduct other criminal activities, armed with knives, swords and other crude weapons. If these youths happen to steal other valuable resources such oil the security forces do not manage to arrest them, they will sell the oil to in the black market and use the funds generated in buying more advanced weapons such guns and this how they start slowly engaging in deep-sea piracy. For those who are courageous to participate in theft engages in oil bunkering. These people also encourage the theft to continue because they coordinate the pirates they capture ships which are transporting oil by availing vessels that they will use in ferrying oil back to the mainland also helping them to get market for this oil.

Another thing that is favouring these activities to grow in the Gulf of Guinea is the culture of these people and how some of them view this act of piracy. It is a fact that those conducting piracy activities are known by those living in their local communities and even their family members (Zabbey, Giadom, \& Babatunde, 2019). However, no one is willing to mention their names to the relevant authorities about the criminal activities that those people do in society. It is also because most of the people in the community have no idea of any person who has ever been arrested, or sentenced to a jail term because of engaging in these criminal activities (Hassan \& Hasan, 2017). On the contrary, they only see these people transforming their lives, having succeeded in getting a ransom for capturing a ship or selling the oil in the black market. Availability of people who are ready to buy the oil which stole from the boat which was meant to be exported to other countries is some of the reason why many youths are prepared to engage in this criminal activities. The fact that it is not necessary for the pirates in the Gulf of Guinea to wait for ransom form the owner of the ships they capture is the reason why most of the youths have attracted to this business. If those who succeed in seizing a ship think that it is risky for them to wait for the ransom, they will quickly call those engaging in oil bunkering to come with their vessels in so that they can transfer the content of the captured ship and takes this oil to the black market. These activities are giving many youths money to the extent that no one is considering it illegal activity (Forster, 2016). Most of the parents of these young men who are involved in these activities are aware that their sons are in this illegal business of buying and selling oil in the black market but because they are getting financial assistance from them, have ever cautioned their sons of possible jail term if the government will catch them.

The figure below shows the concentration of sea criminals in the Gulf of Guinea (Johnson, 2018). 


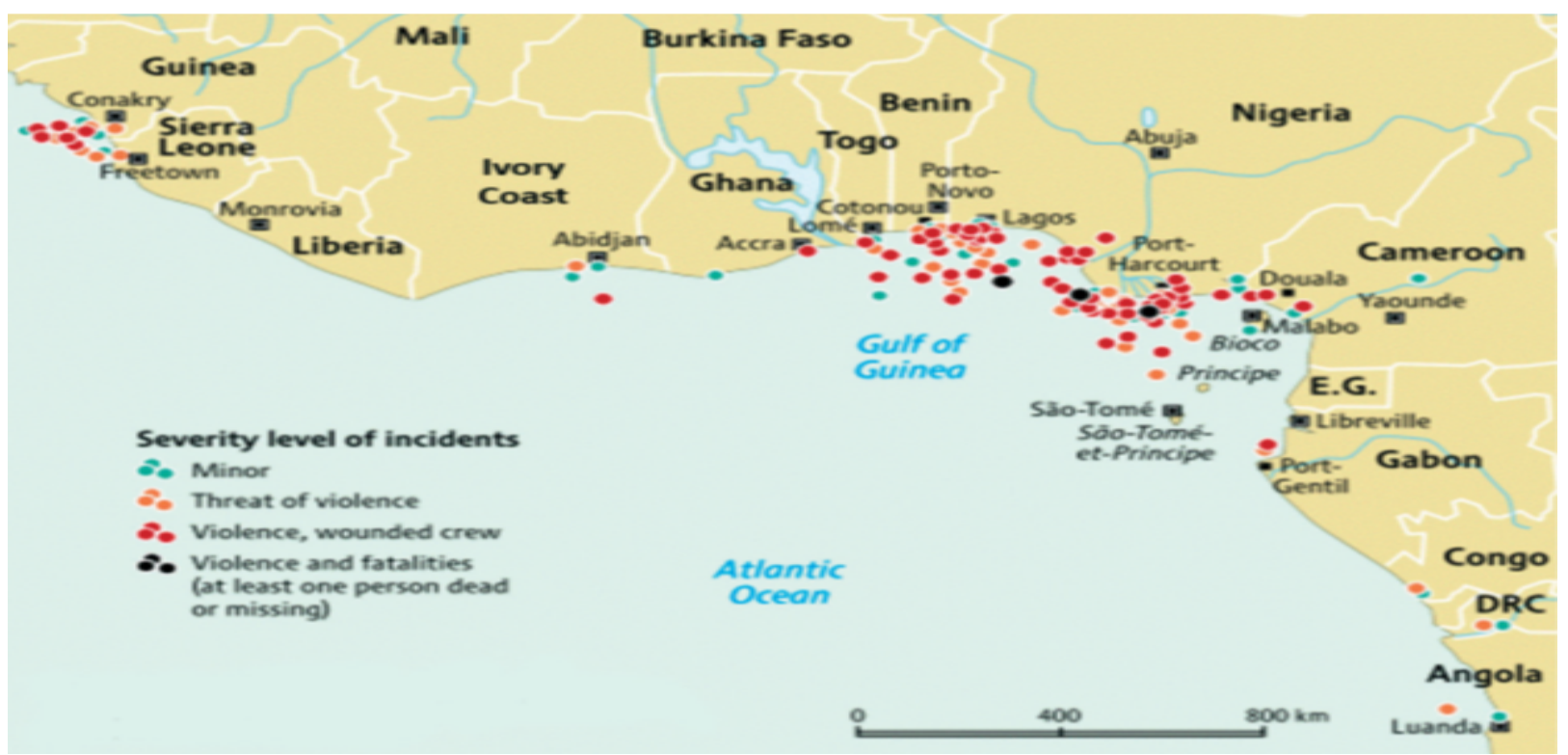

Source: GISIS, IMO, UNITAR/UNOSAT, 2014.

\section{TECHNOLOGICAL}

Advancement of technology has both positive and negative impact on maritime security in the Gulf of Guinea. First, technological advancement has made it possible for the engineers to design big containers which can be used to transport oil across the Atlantic Ocean. The ships living the gulf of guinea with big tanks shows it is carrying a lot of petroleum products in them. It, therefore, attracts many pirates to target those ships because they know that if they succeed in capturing those ships, they will charge the owners a lot of money for them to release such ships (Allen, 2017). It is because the pirates know that the owner must have paid a lot of money in buying the commodity is being transported and will not be willing to lose the entire content to the pirates. Therefore, many pirates have been targetting those ships, which makes it hard for them to reach their destination successfully unless they are under surveillance of the security agencies operating in that region.

The pirates also use sophisticated weapons in which they used to attack the ships. Since it could not be safe to come close to the vessels ferrying expensive luggage because of possibilities of the presence of the security officers, the pirates use the long-range weapons to attack the target ships form a long distance. In this way, they will be able to control such a ship even unpack its content, which they have to sell them the black market. Some of the pirates are people who are well conversant with technology and are capable of disconnecting the communication equipment from the captured ships. The ships will lack communication with those tracking it from the mainland, thus making it hard for the maritime security agencies to trace such as ship while in the deep sea (Jacobsen \& Nordby, 2015).The development of the speed boats is also an advantage to the pirates operating in this region. After hijacking and stealing what they wanted from the ship, the pirates will use the speed boats to escape from the scene of the crime in case they hear or see the security ships are approaching them. They will use the boats to speed away from that scene so that no one will question them about the vessel which had been affected. These factors are favouring the pirates to conduct their activities in the see. Also, when they capture a ship, they use technology to communicate with their colleagues who are at the harbour to bring other vessels that will be used to ferry the content from the one they had captured. It thus becomes hard for security agencies to eliminate these individuals in the ocean (Gold, 2016). 
On the side of the security agencies, there is also an application of the technology in their work. However, the government in this region provides boats and other equipment which are not suitable for the forces to use them for the deep sea operation. The police officers will thus operate in most case in the mainland and the coastal waters. Also, the technology employed in the design of the boats and ship they are using is not capable of chasing the pirates who will quickly disappear into the deep waters. The security provided by the nations in the Gulf of Guinea is not capable of offering sufficient maritime security in this region. Therefore by they rely on international forces such as Interpol policing and Dutch navy forces who have started offer protection in the Gulf of Guinea. These global forces have the equipment and modern technology which will enable them to trace a ship from a distance; thus they can start approaching even before they are noticed by the pirates (Gottlieb, 2017). Their boats have employed modern technology, which means that they have suitable defence mechanism and high speed, which is capable of chasing the pirates in the sea. Again they have advanced weapons that are capable of attacking pirates if they happen to engage the forces with their weapons.

\section{ENVIRONMENTAL}

There has been an increase in oil exploration in the last four decades in the Gulf of Guinea. One of the leading countries in oil exploration in this region is Nigeria. Since the discovery of oil, there are many cases of environmental pollution which have taken place mainly in the areas which extraction of fuel takes place. One of such regions which have been affected with the oil exploration in Nigeria is the Niger Delta. Initially, this region was conducive for agricultural production and fishing in the river Niger (Osinowo, 2015). Most people engaged in fishing and farming in this area. However, with the onset of oil exploration, there has been continuous pollution of the land and water from oil spillage, and leakage of natural gas into the atmosphere has made it hard for the farmers to continue to practice agricultural activities in this region. The entire population in the region had to relocate into other areas where they will get space to do farming or engage in other activities. For those who did not mage to get another place to do agriculture were affected, and they had to look for jobs as an alternative source of income. However, many people who could get jobs owing to the rise of population in the nation (Sibley, 2016). Many people are struggling to make ends meet because of lacking land to practice agriculture and the fact that there are not enough jobs in the nation to observe all people who are looking for employment.

The destruction of the environment has contributed to the rise of insecurity in the Gulf of Guinea. It is because all the people who used to be busy conducting farming activities are now forced in to engage in other things which will earn them a living. Since petroleum activities are the only activities which are lucrative because of the cash generated from it, many youths have rushed to engage in oil bunkering and thus end up being recruited into sea robberies and piracy activities in the deep seas (Schofield, \& Ali, 2015). These events have led to the increase in illegal activities in the ocean. It, therefore, makes it hard for the concern authorities to deal with piracy in the sea.

The nature of the environment in the coastal waters and the deep sea does not favour the pirates in the Gulf of the guinea to hold the captured ships for long compared with Somalia pirates in eastern Africa. Somali pirates have an advantage because their region is occupied with many terrorists who are the parts of the pirates (Mandanda, \& Guo, 2016). There is also no steady government in Somalia, and thus it favours the pirates to hold the ships for long when they are negotiating for the ransom they need with its owners. In the Gulf of Guinea, however, the government in this region are functional, and thus it is not possible for the pirates to capture the big ship in deep water and direct it to the harbour where they will hold it while 
waiting for the owners to send the money they need. It is because, at the port, the pirates will be overpowered by the police offices in the mainland and those operating in the local water. It is because at these areas, the police officers have more power and thus they can easily overpower the people who have hijacked any particular ship. Due to such challenge, the environment of the coastal waters and even at the harbour is not suitable for the pirates to conduct their activities there (Prins, \& Daxecker, 2018). The environment in the deep sea, therefore, favours the pirates in the Gulf of guinea compared with areas which are close to the harbour

The presence of the Dutch forces and in the Interpol police who patrol in the deep sea helps to make this environment more secure by mitigating the acts of pirates. It is because it is not possible for individuals to attempt to hijack a sea vessel when such security agencies are in the vicinity, owing to the type of machinery they possess (Adibe, Nwangwu, Ezirim, \& Egonu, 2018). They will also have to disconnect the communication equipment quickly in the ship so that those in charge of the vessel will not be in a position to trace it faster and thus ask the forces concerned with security in the ocean to help them rescue it. It also explains why most of the pirates in the deep sea will prefer to transfer the content that the ship was transporting to their vessels and disappear from the vicinity. By the time the captured ship will have been identified, the pirates will have gone away and will not be in position

\section{LEGAL}

When it comes to legislation, many countries in this region lack the right mix of the jurisdictional provisions and the prosecutorial and judicial capacity to undertake the correct prosecutions. They also require the relevant links which will enable them to conduct a proper survey on the impact of the piracy and robberies happening in the sea (Kamal-Deen, 2015). These factors have made it impossible for the maritime security agencies to be efficient in counter-attack piracy in the deep sea. The authorities of the countries in this region accepted that their laws need to be revised so that it can include on matters of piracy and how such a person should be sentenced according to the constitution of the land. According to the research conducted at Kofi Annan International peacekeeping College Training Center, it was discovered that in Ghana the maritime laws are outdated and need to be revised if they will have to fight piracy activities effectively. The case is the same in most of the countries in the Gulf of Guinea (Hassan \& Hasan, 2017). It is not possible to form this nation to fight piracy because they lack legislation on criminal activities taking place in the deep sea such as drug trafficking, people smuggling, and robbery in the deep sea. The pirates have taken advantage of this inefficiency of the government to conduct their criminal activities. In the process, many companies have suffered losses because of the robberies and the piracy that is taking place in the deep sea. Lack of proper maritime security in the region It also attracts even more pirates from other countries who are expert in these activities to bring their equipment in the Gulf of Guinea where they use them in to facilitate their agenda (Cornell, 2018). They are doing this because they have discovered that it is more likely for one succeed in this region when it comes to capturing of ships compared with other regions waters of other counties which have sufficient laws and well-organised security that are monitoring their seas.

It is therefore essential that the international community, through bodies such as the united nation security council to considers assisting the countries at the Gulf of the guinea to revise their laws. It is necessary for them to be sufficient in fighting criminal activities that are taking place in the deep sea - considering that the piracy activities does not affect the ships in the deep seas only but also other events that are taking place in the harbour (Wardin \& Duda, 2015). The presence of pirates in the Gulf of Guinea also does not affect the companies from this region only but also the ships from other countries which are crossing this region. 
Furthermore, the trade that is taking place between the counties in West Africa and the rest of the world will be affected, which in turn hinder the economic development in this region.

Another legal matter which is hindering the effort to fight the piracy in this region is the ineffective implementation of the proposed security programs. The countries in this region had been called to come together in 2006 to implement international conventions which will help them in fighting the criminal's groups are existing in the sea water that is under their control. However, when it came to the individual nations to carry out their mandate, there is little effort that seen from these nations in trying to implement those conventions (Wang \& Tao, 2018). These issues are being experienced even though there are external actors like the international maritime organisation who worked with the individual countries in the region to help them on the procedures which they should adopt in implementing the proposed conventions. It has been a challenge in the Gulf of Guinea in combatting the piracy issues, which is meant to boost the maritime security in the region. The declaration and conventions have been drafted are currently existing, but the problem is that there is little that those nations are doing to see that the proposed laws are working in their territories.

Another challenge existing in legal matters is the lack of people who can avail the necessary evidence which can be used against those suspected of having been engaging in piracy. Due to this, the courts are not in a position to offer the right penalty concerning the people suspected for such to be involved with criminal activities in the sea. Most of the counties in West Africa have acknowledged being experiencing these problems. In the other hand, these legal challenges are encouraging the pirates to continue with their activities (Wang \& Tao, 2018).

The following graph shows the trend of piracy activities in the Gulf of Guinea (Wang \& Tao, 2018).

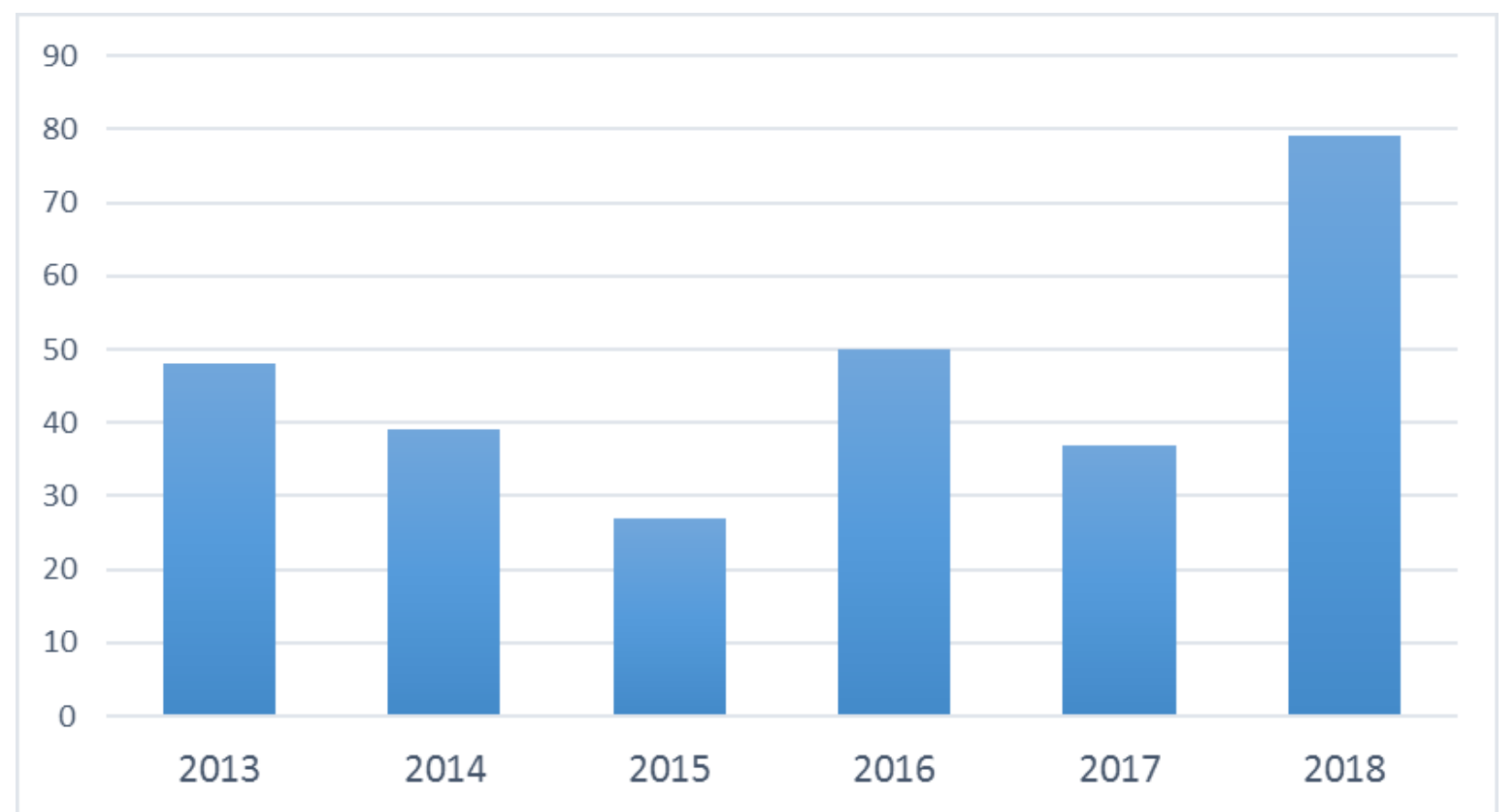

Source: Tradingeconomic.Com | Bureau of Statistics, Nigeria.

\section{References}

Adibe, R., Nwangwu, C., Ezirim, G. E., \& Egonu, N. (2018). Energy hegemony and maritime security in the Gulf of Guinea: rethinking the regional trans-border cooperation approach. Review of African Political Economy, 1-11.

Ali, K. D., (2017). 7 Anti-Piracy Responses in the Gulf of Guinea: Addressing the Legal Deficit. In Ocean Law and Policy (pp. 203-219). Brill Nijhoff. 
Allen, C. D., (2017). Pirates in West Africa and Somalia. In Violent Non-State Actors in Africa (pp. 301-321). Palgrave Macmillan, Cham.

Brown, T. M., (2016). Piracy waters: notes from the field (s). Loyola Maritime Law Journal, 15(2), 189-215.

Cornell, S. C., (2018). Piracy in the Gulf of Guinea: Responses under International Maritime Law.

Denton, G. L., \& Harris, J. R. (2019). The Impact of Illegal Fishing on Maritime Piracy: Evidence from West Africa. Studies in Conflict \& Terrorism, 1-20.

Forster, B. A., (2016). MODERN MARITIME PIRACY: An Overview of Somali Piracy, Gulf of Guinea Piracy and SouthEastAsian Piracy. American Historical, 2032.

Frank, N. J., (2017). Gulf of Guinea and Security Challenges: the Nigerian Experience (Doctoral dissertation).

Gold, M., (2016). And Justice for All: An Analysis of a Shipowner's Duty of Care in Piracy and Armed Robbery Attacks. J. Mar. L. \& Com., 47, 501.

Gottlieb, Y. (2017). International cooperation in combating modern forms of maritime piracy: Legal and policy dimensions.

Hasan, S. M., \& Hassan, D. (2016). Current arrangements to combat piracy in the Gulf of Guinea region: an evaluation. J. Mar. L. \& Com., 47, 171.

Hassan, D., \& Hasan, S., (2017). Effectiveness of the Current Regimes to Combat Piracy in the Gulf of Guinea: An Evaluation. African Journal of Legal Studies, 10(1), 35-65.

Jacobsen, K. L., \& Nordby, J. R. (2015). Maritime security in the Gulf of Guinea. Royal Danish Defence College Publishing House.

Johnson, I., (2018). Piracy as a Threat to Africa's Security and Economic Development. Covenant University Journal of Politics and International Affairs, 6(2).

Kamal-Deen, A., (2015). The anatomy of Gulf of Guinea piracy. Naval War College Review, 68(1), 93-118.

Mandanda, D. E., \& Guo, P., (2016). Differences and Similarities between the Gulf of Guinea and Somalia Maritime Policy: Lessons Gulf of Guinea Coastal State Should Learn from Somali Piracy. JL Poly \& Globalization, 56, 40.

Nelissen, T., (2018). REFLECTIONS ON HOW TO TURN A WORM INTO A GIANT: A Strategic Management Approach to Bridge the Gap towards a Security and Defence Union.

Omeje, K., (2017). High stakes and stakeholders: Oil conflict and security in Nigeria. Routledge.

Osinowo, A. A. (2015). Combating Piracy in the Gulf of Guinea. NATIONAL DEFENSE UNIV FORT MCNAIR DC AFRICA CENTER FOR STRATEGIC STUDIES.

Oyewole, S., (2016). Suppressing maritime piracy in the Gulf of Guinea: the prospects and challenges of the regional players. Australian Journal of Maritime \& Ocean Affairs, 8(2), 132-146.

Prins, B. C., \& Daxecker, U. (2018). Maritime Crime in Civil Conflict: An Extension to the Maritime Piracy Event and Location Data Project. University of Tennessee, Knoxville, United States.

Schofield, C., \& Ali, K. D. (2015). Combating piracy and armed robbery at sea: from Somalia to the Gulf of Guinea. In Routledge Handbook of Maritime Regulation and Enforcement (pp. 313-328). Routledge.

Sibley, C., (2016, June). Be Alert and Stay the Course: An Agent-Based Model Exploring Maritime Piracy Countermeasures. In International Conference on Social Computing, Behavioral-Cultural Modeling and Prediction and Behavior Representation in Modeling and Simulation (pp. 356-365). Springer, Cham.

Sposato, J., (2016). Counter Piracy In The Gulf Of Guinea: A Whole-Of-Government Approach. Air War College Maxwell AFB United States.

Wang, Q., \& Tao, P., (2018). Survey on Reviews of Global Piracy Activities and the Response Measures.

Wardin, K., \& Duda, D., (2015). Effectiveness of Measures Undertaken in the Gulf of Guinea Region to Fight Maritime Piracy. Safety of Marine Transport: Marine Navigation and Safety of Sea Transportation, 213.

Zabbey, N., Giadom, F. D., \& Babatunde, B. B. (2019). Nigerian Coastal Environments. In World Seas: an Environmental Evaluation (pp. 835-854). Academic Press.

Comparison of the region industry income 